\title{
A micro-Raman spectroscopic investigation of leukemic U-937 cells treated with Crotalaria agatiflora Schweinf and the isolated compound madurensine
}

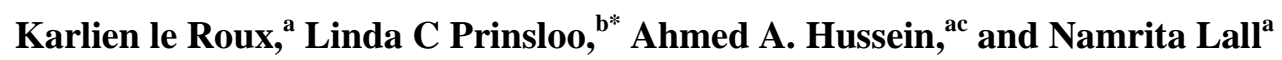 \\ ${ }^{a}$ Department of Plant Science, University of Pretoria, Pretoria, 0002, South Africa \\ ${ }^{b}$ Department of Physics, University of Pretoria, Pretoria, 0002, South Africa \\ ${ }^{a, c}$ Physical address: Department of Medicinal Plants, National Research Centre, El-Tarir Street, Cairo, Egypt
}

*Corresponding Author: Tel: 2712420 2458. Fax: 27123625297.

e-mail address: linda.prinsloo@up.ac.za

\begin{abstract}
In South Africa traditional medicine plays an important role in primary health care and therefore it is very important that the medicinal use of plants is scientifically tested for toxicity and effectiveness. It was established that the ethanolic extract of the leaves of Crotalaria agatiflora, as well as the isolated compound madurensine, is moderately toxic against leukemic U-937 cells. Light microscopic investigations indicated that symptoms of cell death are induced during treatments, but flow cytometry analysis of treated cells, using annexin- $\mathrm{V}$ and propidium iodide, showed that apoptosis and necrosis are insignificantly induced. The Raman results suggested that protein extraction and DNA melting occur in the cells during treatment with the ethanolic extracts ( $\mathrm{IC}_{50}$ value $73.9 \mu \mathrm{g} / \mathrm{mL}$ ), drastically changing the molecular content of the cells. In contrast, treatment with madurensine ( $\mathrm{IC}_{50}$ value $136.5 \mu \mathrm{g} / \mathrm{mL}$ ), an isolated pyrrolizidine alkaloid from the ethanolic extract of the leaves, did not have the same effect. The results are also compared to that of cells treated with actinomycin D, a compound known to induce apoptosis.
\end{abstract}


The investigation showed that micro-Raman spectroscopy has great promise to be used for initial screening of samples to determine the effects of different treatments on cancerous cell lines together with conventional methods. The results highlight the fact that for many natural products used for medicinal purposes, the therapeutic effect of the crude plant extract tends to be significantly more effective than the particular action of its individual constituents.

\section{Graphical abstract}

Leukemic U-937 cells were treated with different concentrations of the ethanolic extract of

Crotalaria agatiflora subspp. agatiflora and the isolated pyrrolizidine alkaloid, madurensine.

Different biochemical responses were observed with micro-Raman spectroscopy after treatments.

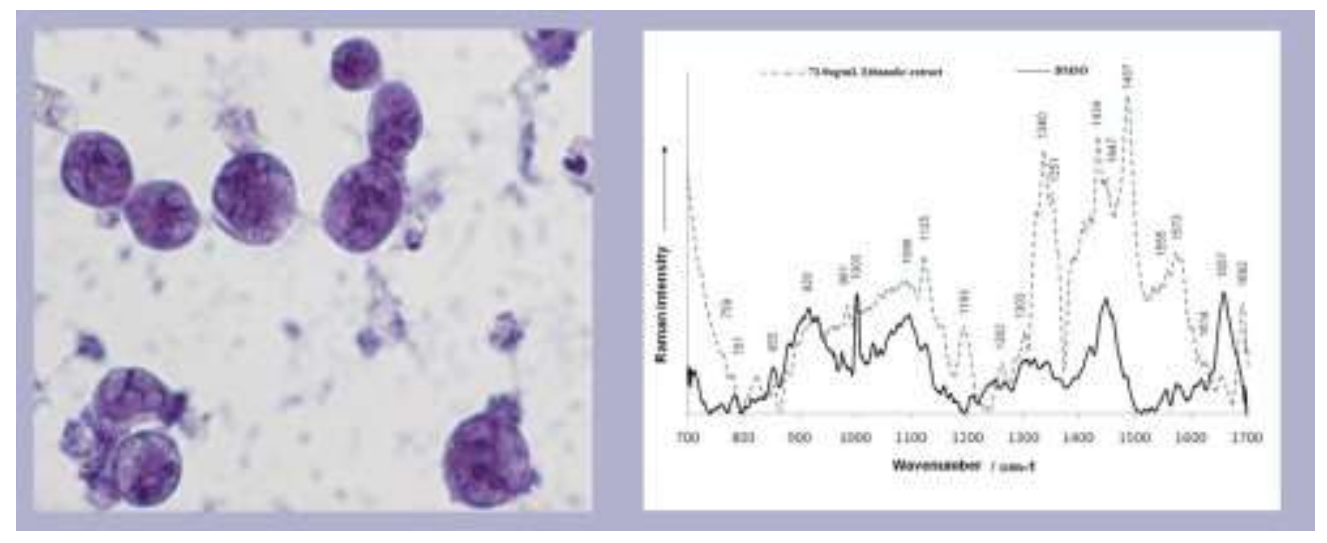

\section{Highlights}

- Crotalaria agatiflora Schweinf has an ethnobotanic use against cancer.

- An ethanolic extract of the plant was tested against leukemic U-937 cells.

- Raman spectra showed changes in cell morphology and biochemical constituents.

- Crude plant extracts might be more bioactive than isolated compounds.

- Raman spectroscopy has potential as an initial screening tool in phytomedicine.

Keywords: Crotalaria agatiflora; Raman spectroscopy; Cytotoxicity; Flow cytometry 


\section{Introduction}

In South Africa traditional medicine plays an important role in the primary healthcare of people living in rural areas due to the inaccessibility and high cost of western medicine, as well as the cultural importance of traditional healers. South Africa is well known for high biodiversity and plants are commonly used for medicinal purposes. Approximately 500 species are traded daily in large quantities at informal traditional medicine markets (locally known as "muti" markets). It is therefore very important that the medicinal use of the plants is scientifically tested for toxicity and effectiveness.

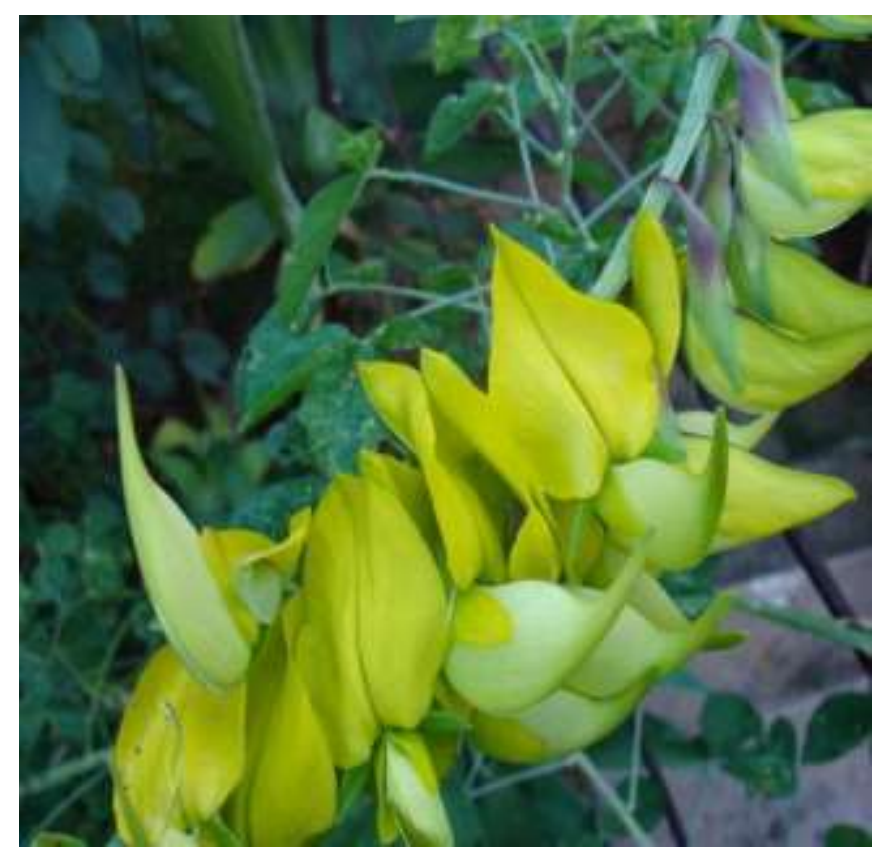

Fig. 1. C. agatiflora subspecies agatiflora Schweinf.

Recently, the selective toxicity of water and ethanol extracts of the leaves of Crotalaria agatiflora subsp. agatiflora Schweinf ( Fig. 1) on various cancerous cell lines was investigated, with the aim to determine the active compounds and ultimately evaluate possible mechanisms of actions of bioactive samples [1] and [2]. Crotalaria agatiflora, a shrub also known as canary bird bush, is 
native to east and northern Africa and is commonly found in disturbed areas in South Africa, for example along roadsides. C. agatiflora was selected based on its phytochemical constituents and ethnobotanical use against cancer [3] and [4]. This plant also has antibacterial, hypotensive and anti-spasm activities and anti-oxidant as well as anti-cancer activities were investigated.

It was established that the ethanolic extract of the leaves of C. agatiflora, as well as madurensine, an isolated pyrrolizidine alkaloid from the ethanolic extract of the leaves, are moderately toxic on leukemic U-937 cells with $\mathrm{IC}_{50}$ (inhibitory concentration for $50 \%$ of the cell population) values of 73.9 and $136.5 \mu \mathrm{g} / \mathrm{mL}$, respectively, [1] and [2]. Mandurensine had weaker activity in comparison to the crude extract and therefore might not be the only active compound in the extract or alternatively the activity of the extract could be dependent on the synergy between more than one constituent. It was evident that the ethanolic extract had good antioxidant activity, while madurensine had no detectable activity up to a concentration of $100 \mu \mathrm{g} / \mathrm{mL}$ [1] and [2]. Light microscopic investigations indicated that symptoms of cell death were induced during treatments (Fig. 2), but flow cytometry analysis of treated cells, using annexin- $\mathrm{V}$ and propidium iodide, showed that apoptosis and necrosis were insignificantly induced [1] and [2]. Due to inconclusive results obtained regarding the mechanism of action of the ethanolic extract and madurensine, Raman spectroscopy was used in an attempt to understand the mechanism of action on a molecular 

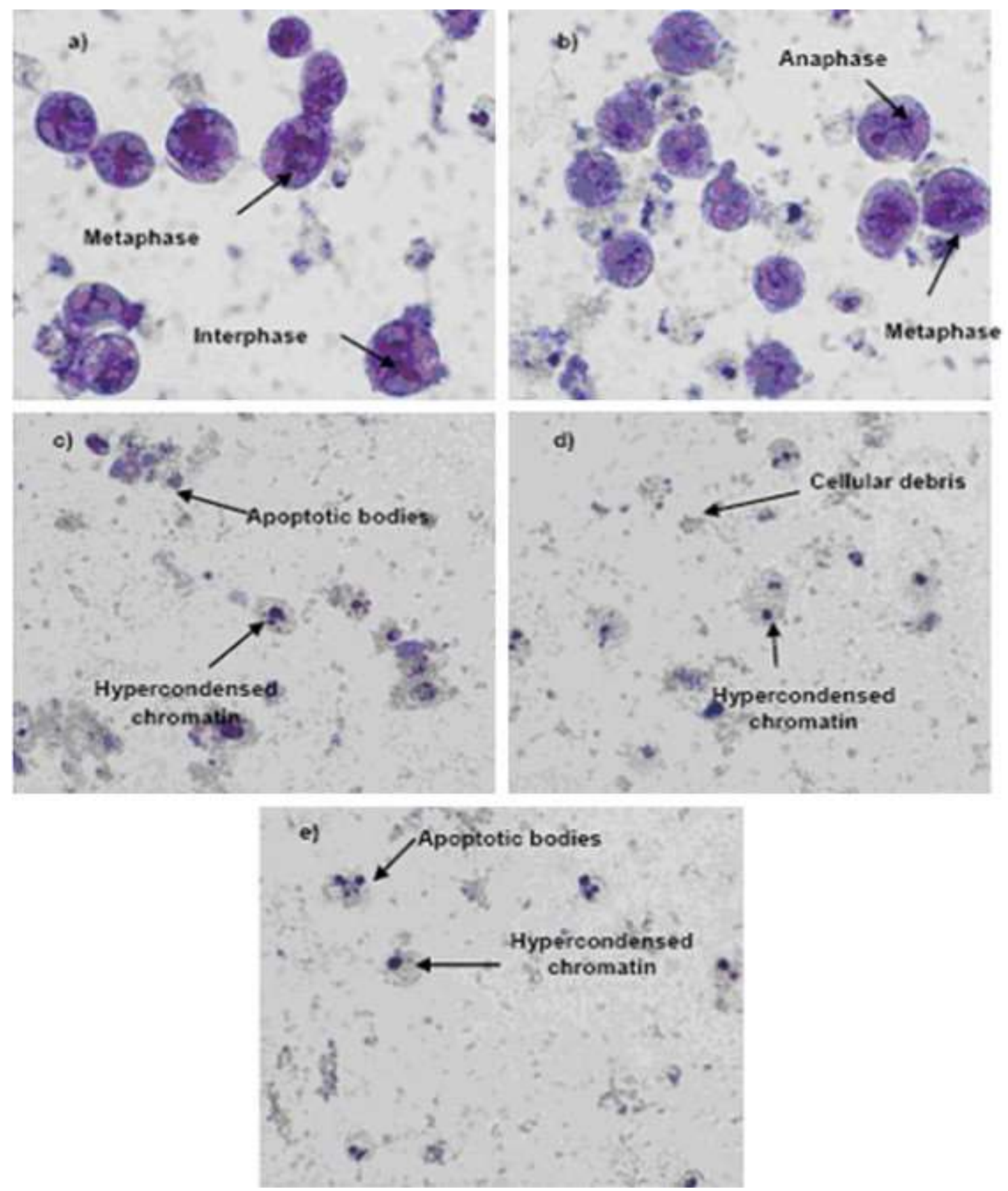

Fig. 2. Haematoxylin and eosin staining of U-937 cells, medium control (a), DMSO treated cells (b), $0.002 \mu \mathrm{g} / \mathrm{mL}$ actinomycin D (c), $73.9 \mu \mathrm{g} / \mathrm{mL}$ extract treated (d) and $147.8 \mu \mathrm{g} / \mathrm{mL}$ extract (e) treated cells after $72 \mathrm{~h}$ of exposure (1000× magnification) [1] and [2].

level, as biomedical sciences, including biochemical and biophysical intracellular investigations of diseases, are increasingly investigated using Raman spectroscopy. Recently the focus has been on 
cancer research since the fundamental understanding of intracellular events, such as mitosis, cell differentiation, cell death, phagocytosis and interactions of drugs within living cells are important considerations when investigating cancer. Conventional assays are widely used in cancer research, notwithstanding the fact that these experiments have long preparation times, use large amounts of cells which need to be labelled and fixed and are damaged after the experiment, rendering them useless for further analysis. In contrast, Raman spectroscopy is a rapid and non-destructive technique for studying biological systems and neither labels nor fixation of cells is required while measurements can be taken in physiological conditions. Proteins, nucleic acids and lipids can be studied within cells as Raman spectroscopy is sensitive to chemical and physical changes of biological molecules. It is therefore possible to differentiate between normal and abnormal cells in tissues; for example the detection of cancerous cells. The distribution of chemicals, induced by a change in physical or chemical conditions, can be measured within the cells at sub-cellular levels as recent research focussing on drug interactions with proteins and DNA has illustrated [5].

\section{Materials and methods}

\section{Cell cultures}

Leukemic U-937 cells were maintained in culture flasks in complete RPMI-1640 medium (Highveld Biological, Johannesburg, South Africa), supplemented with 10\% heat-inactivated fetal bovine serum (FBS) (Hyclone, Separations, Johannesburg, South Africa) and antibiotic cocktail (100 U/mL penicillin, $100 \mu \mathrm{g} / \mathrm{mL}$ streptomycin and $250 \mu \mathrm{g} / \mathrm{L}$ fungizone) (Highveld Biological, Johannesburg, South Africa). Cells were grown and maintained in a humidified atmosphere at $37{ }^{\circ} \mathrm{C}$ and $5 \% \mathrm{CO}_{2}[1]$ and [2].

\section{Sample preparation}

U-937 cells are suspension cells and therefore it was necessary to manipulate the cells to adhere to the glass coverslips. This was achieved by washing the cells three times with a phosphate buffer saline (PBS) to remove all traces of FBS and then re-suspending them in the complete medium 
lacking FBS. The dried ethanolic extracts were dissolved in DMSO (stock solution of $20 \mathrm{mg} / \mathrm{mL}$ ) and actinomycin D dissolved in distilled water (stock solution of $1 \mathrm{mg} / \mathrm{mL}$ ). Exponentially growing U-937 cells were then seeded at one million cells per sterilized coverslip. After $24 \mathrm{~h}$ incubation $\left(37{ }^{\circ} \mathrm{C}, 5 \% \mathrm{CO}_{2}\right)$ to allow the U-937 cells to adhere, the cells were exposed to $73.9 \mu \mathrm{g} / \mathrm{mL}\left(\mathrm{IC}_{50}\right)$ and $147.8 \mu \mathrm{g} / \mathrm{mL}\left(2 \mathrm{IC}_{50}\right)$ of the ethanolic extract of the leaves of C. agatiflora. Additionally in a third experiment cells were exposed to $136.5 \mu \mathrm{g} / \mathrm{mL}$ of the isolated compound madurensine and for comparison purposes the cells were also exposed to the vehicle-treated control (0.74\% DMSO). Furthermore, actinomycin $\mathrm{D}(0.002 \mu \mathrm{g} / \mathrm{mL})$, which is known to induce apoptotic cell death was used as a positive control. Cells were incubated for $72 \mathrm{~h}$ at $37^{\circ} \mathrm{C}$. After $72 \mathrm{~h}$ of incubation the coverslips were removed from the treatments and were air-dried before analyses were carried out [1] and [2].

\section{Raman spectroscopy}

Micro-Raman spectroscopy was performed with a T64000 micro-Raman spectrometer from HORIBA Scientific, Jobin Yvon Technology (Villeneuve d'Ascq, France). The Raman spectra were excited with the $514.7 \mathrm{~nm}$ line of an Innova $70 \mathrm{v}$ argon ion laser from Coherent and the 50x objective of an Olympus microscope was used to focus the laser beam (spot size $\sim 1.0 \mu \mathrm{m}$ ) on the air-dried individual cells. An integrated triple spectrometer was used in the double subtractive mode to reject Rayleigh scattering and dispersed the light onto a liquid nitrogen cooled Symphony CCD detector. The spectrometer was calibrated with the silicon phonon mode at $520 \mathrm{~cm}^{-1}$.

The optimal parameters for recording Raman spectra of the samples were first determined by recording spectra of a test sample with varying laser powers. In accordance with results reported in the literature is was found that for the $514.7 \mathrm{~nm}$ laser line the power should be less than $5 \mathrm{~mW}$ at the samples to avoid morphological changes in the cells [5] and [6]. The laser power used for the 
control samples (untreated, DMSO and actinomycin D) was $3 \mathrm{~mW}$, but was reduced to $2 \mathrm{~mW}$ for the treated samples due to an increase in sensitivity to the laser light. Different acquisition times ranging from 60 to $300 \mathrm{~s}$ and accumulations varying between 2 and $10 \mathrm{~s}$ were also tested and optimised to $150 \mathrm{~s}$ with ten accumulations. These experimental conditions were kept constant for all measurements and three cells per sample were analysed.

\section{Data processing}

The Labspec 6.0 software was used to fit and subtract a fifth order polynomial function from all spectra to obtain a zero baseline in order to make comparisons between spectra possible. A 5 degree linear Savitsky-Golay smoothing procedure was applied to all the spectra ${ }^{[4]}$. The intensity of the spectra was adjusted to make comparisons possible between spectra recorded with a laser power of $3 \mathrm{~mW}$ and $2 \mathrm{~mW}$ respectively.

\section{Results and Discussion}

\section{Micro-Raman spectroscopic investigation of $U-937$ cells}

No morphological damage was observed and all the cells looked healthy (Fig. 2). Raman spectra recorded on different cells, as well as on different positions within the cells, were similar. The nucleus in monocytic (in this case leukemic) cells occupies a very large volume of the cell, leaving little space for the cytoplasm and in the absence of nuclear staining it is impossible to determine where cell components are located. It was previously also established that U-937 cells have homogeneously distributed proteins and lipids [7]. All spectra were recorded in the middle of the cells, which gave reproducible Raman spectra. A representative Raman spectrum of U-937 cells is shown in Fig. 3 and tentative assignments of the bands are listed in Table 1. The major biochemical constituents that occur in U-937 cells are proteins, nucleic acids and lipids. A Raman spectrum of a cell is therefore a superimposition of the Raman spectra of many different chemical entities and not always easy to analyse as many bands occur at the same positions and overlap. Marker bands, which are specific to a certain type of molecule, were assigned for some of the components. The strongest band in the spectrum of a specific compound cannot always be used as a marker as it may 
overlap with bands from other molecules and not all the constituents can always be identified through their Raman spectra as some of the bands may be hidden.

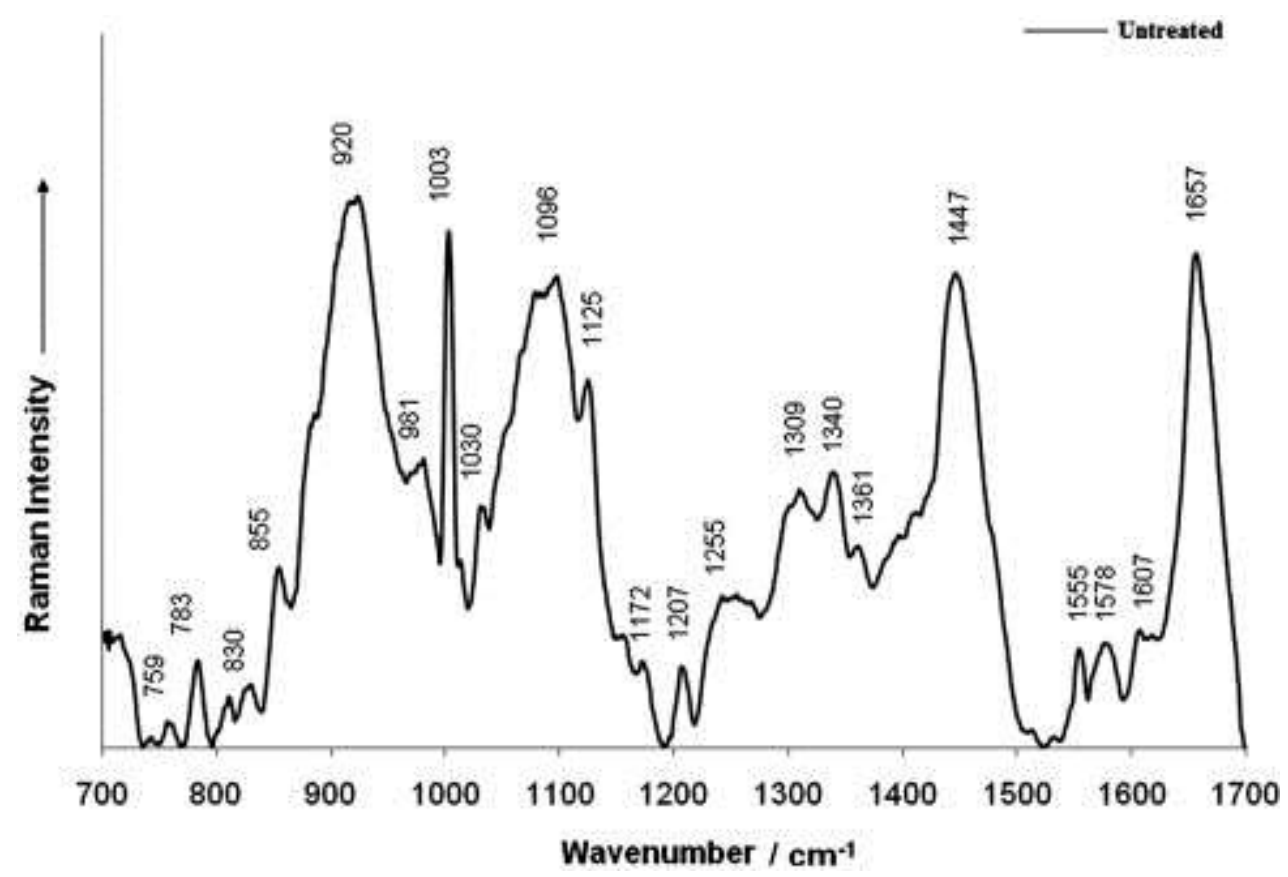

Fig. 3. Representative Raman spectrum of cancerous U-937 cells and medium reference spectrum.

Table 1. Tentative Raman assignments for untreated U-937 cells.

\section{Assignments}

Peak position

$\left(\mathrm{cm}^{-1}\right)$

$759 \mathrm{wn}$

$783 \mathrm{wn}$

$830 \mathrm{mn}$

$855 \mathrm{mn}$

860 wn

$920 \mathrm{sb}$

$981 \mathrm{mn}$
Proteins

Tryptophan [6]

Tyrosine [6]

Tyrosine [5]

conformation $(\mathrm{C}-\mathrm{C}$ stretch of proline

ring, valine and protein backbones [7] and [10]

Cell culture medium [7]
Cytosine, Thymine, Uracil, O-P-O

backbone [5], [6] and [10] 


\begin{tabular}{|c|c|c|c|}
\hline \multirow{2}{*}{$\begin{array}{c}\text { Peak } \\
\text { position } \\
\left(\mathrm{cm}^{-1}\right)\end{array}$} & \multicolumn{3}{|c|}{ Assignments } \\
\hline & Proteins & Nucleic acids & Lipids \\
\hline $1003 \mathrm{sn}$ & $\begin{array}{l}\text { Phenylalanine (ring breathing mode) [5], } \\
{[6] \text { and [10] }}\end{array}$ & & \\
\hline $1031 \mathrm{mn}$ & Cell culture medium [7] & & \\
\hline $1096 \mathrm{mb}$ & & DNA (O-P-O- stretch) [7] and [10] & \\
\hline $1125 \mathrm{mn}$ & & & $\mathrm{C}-\mathrm{C}$ stretching [5] \\
\hline 1172 wn & Tyrosine, Phenylalanine [5] and [7] & & \\
\hline $\begin{array}{l}1193- \\
1207 \mathrm{mn}\end{array}$ & Tyrosine, Phenylalanine [6] and [7] & & \\
\hline $\begin{array}{l}1255- \\
1268 \text { wn }\end{array}$ & Amide III [6] and [7] & & \\
\hline 1309 wn & & Adenine [14] & \\
\hline 1340 wn & C-H deformation, Tryptophan [6] and [7] & $\begin{array}{l}\text { Polynucleotide chain (DNA purine } \\
\text { bases, specially Adenine) [5] and [10] }\end{array}$ & \\
\hline $1361 \mathrm{mn}$ & & Thymine and adenine [7] & \\
\hline $1447 \mathrm{sb}$ & $\mathrm{CH}_{2}$ stretching [6] and [7] & & $\begin{array}{l}\mathrm{CH}_{2} \text { stretching } \\
{[6] \text { and [7] }}\end{array}$ \\
\hline 1490 wn & & Adenine [11] & \\
\hline $1555 \mathrm{mn}$ & Amide III (C-N stretching mode) [15] & & \\
\hline $\begin{array}{l}1573- \\
1580 \mathrm{mn}\end{array}$ & & $\begin{array}{l}\text { Guanine, Adenine ring stretch } \\
{[8] \text { and [10] }}\end{array}$ & \\
\hline 1607 wn & Phenylalanine and tyrosine [5] & & \\
\hline $1657 \mathrm{sb}$ & Amide I [16] & & $\mathrm{C}=\mathrm{C}$ stretch $[6]$ \\
\hline
\end{tabular}

Abbreviations regarding Raman peaks: s, strong; m, medium; w, weak; n, narrow; b, broad.

Representative bands for DNA consist of the DNA backbone vibrations at 830 and $1093 \mathrm{~cm}^{-1}$ as well as adenine $\left(1490 \mathrm{~cm}^{-1}\right)$ and guanine $\left(1579 \mathrm{~cm}^{-1}\right)$. The Raman spectrum of a protein is 
characterised by Amide I $\left(\sim 1658 \mathrm{~cm}^{-1}\right)$, Amide II $\left(\sim 1607 \mathrm{~cm}^{-1}\right)$ and Amide III $\left(\sim 1255 \mathrm{~cm}^{-1}\right)$ vibrations of the peptide backbone [6], [7] and [9]. Amide I and Amide III bands are classical Raman markers for protein conformation as the Amide II band is usually weak in a Raman spectrum and can in practice usually not be used as a marker. Spectroscopic markers for lipids can be divided into bands originating from the acyl chain and the lipid head group. Acyl chain markers include a prominent band at $1440 \mathrm{~cm}^{-1}$ corresponding to $\mathrm{CH}_{2}$ bending vibrations, while the $1460 \mathrm{~cm}^{-1}$ band is representative of $\mathrm{CH}_{3}$ bending modes. All 'trans' skeletal vibrations are represented around 1133 and $1064 \mathrm{~cm}^{-1}$ by $\mathrm{C}-\mathrm{C}$ stretching bands. Head group markers include the band at $\sim 860 \mathrm{~cm}^{-1}$ which is assigned to a phosphate group characteristic to most phospholipids [9]. A marker band which is specific to monocytes (U-937 cells are monocytic) occurs at $\sim 1207 \mathrm{~cm}^{-1}[8]$.

In untreated leukemic U-937 cells, amino acids that can be identified by their Raman bands are tryptophan (759 and $\left.1340 \mathrm{~cm}^{-1}\right)$, tyrosine $\left(830,1172\right.$ and $\left.1207 \mathrm{~cm}^{-1}\right)$ phenylalanine $\left(1003 \mathrm{~cm}^{-1}\right)$

and phospholipids $\left(\sim 860 \mathrm{~cm}^{-1}\right)$ [5], [6], [7] and [10]. The band centred at $\sim 783 \mathrm{~cm}^{-1}$ was also previously found in bacteria and HeLa cells and assigned to the $\mathrm{C}-\mathrm{C}$ breathing vibrations of cytosine, thymine and uracil [7]. The weak band at $\sim 1580 \mathrm{~cm}^{-1}$ is assigned to nucleic acid ring stretches of guanine and adenine. The peak $\sim 1096 \mathrm{~cm}^{-1}$ is associated with $\mathrm{O}-\mathrm{P}-\mathrm{O}$ backbone vibrations of DNA and the peak at $783 \mathrm{~cm}^{-1}$ suggests that the DNA is B-form [6], [10], [11] and [12]. However, as the B-form of DNA has only been observed when cells are in the hydrated state this assignment should be verified with FTIR measurements.

\section{Raman spectra of vehicle treated (DMSO) cells}

Vehicle treated cells appeared to have had minimal morphological damage (Fig. 2) and the Raman spectra recorded for untreated and vehicle treated cells are very similar (Fig. 4). The relative intensity of the bands at $710,920,1447$ and $1657 \mathrm{~cm}^{-1}$ assigned to proteins and lipids (Table 1), changed after treatment. Two opposing interpretations have been used to discuss intensity changes of peaks during treatments. The first interpretation states that as the intensity of Raman peaks depends linearly on the concentration of molecules in a sample, a lower concentration will imply that the associated Raman peak decreases in intensity [13]. The second interpretation suggested that 
when molecules denature or lose their form and function the intensity of some Raman peaks will increase [7]. The intensity of the peak around $1657 \mathrm{~cm}^{-1}$ (Amide I) slightly decreased in intensity, which could be due to a lower concentration of proteins after DMSO treatment. The peak at $\sim 1003 \mathrm{~cm}^{-1}$ associated with phenylalanine slightly increased in intensity, possibly an indication of denaturation of the amino acid. Furthermore, a new band associated with guanine and adenine base pairs appeared at $1420 \mathrm{~cm}^{-1}$ indicating that some changes also occurred in the DNA of DMSO treated cells [16]. This result was confirmed with flow cytometry experiments, where it was found that the viability (number of cells capable of living) of cells decreased slightly after $72 \mathrm{~h}$ treatment with DMSO [1] and [2].

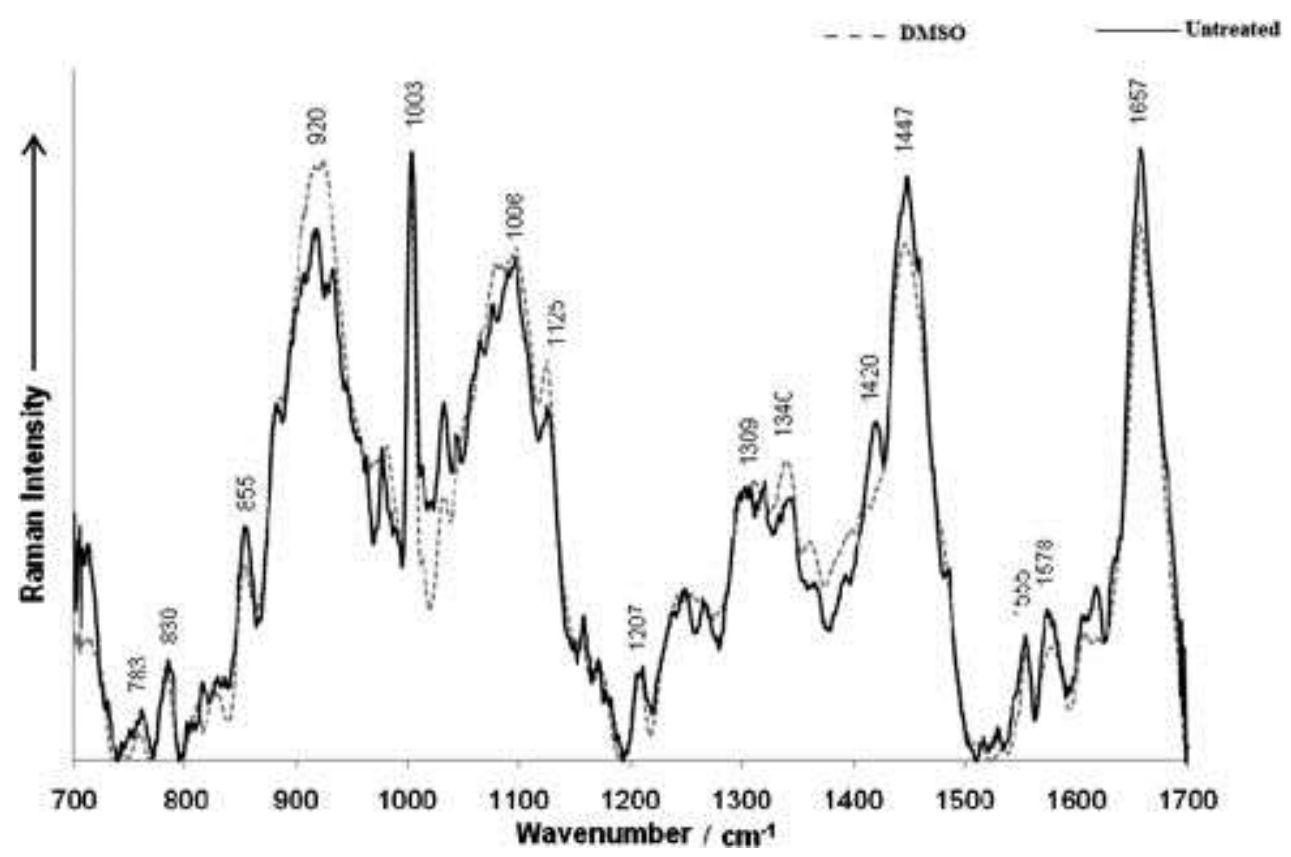

Fig. 4. Representative Raman spectra of untreated and vehicle (DMSO) treated U-937 cells.

\section{Impact of Actinomycin D on U-937 cells}

Morphologically, treated cells were found to be much smaller in comparison to untreated cells (Fig. 2c). Cells showed symptoms of apoptosis after $72 \mathrm{~h}$ incubation, which was confirmed with flow cytometry and was expected, as it has been shown previously that Actinomycin D induced apoptosis [1] and [17]. Bands originating from both proteins and lipids decreased dramatically, which has a direct relationship with changes in DNA (Fig. 5). Bands assigned to nucleotides all decreased $\left(1096,1309,1340\right.$, and $\left.1578 \mathrm{~cm}^{-1}\right)$. The mechanism of action of actinomycin $\mathrm{D}$ had been 
investigated previously with crystallography and it was found that this antibiotic is capable of forming complexes with DNA. More specifically actinomycin D intercalates into DNA. Both amino acids (threonine) that form part of the structure of actinomycin D reside in the minor groove of DNA. Hydrogen bonds form to N2 and N3 atoms of guanosine (guanine bound to sugar) [18]. The decrease of peak intensity in the Raman spectrum is in agreement with the established fact that actinomycin D prevents amino acid and protein transcription and evidently translation as well as DNA strands that break. Similar results have previously been obtained with Raman spectroscopy on human gastric cells (SGC-7901 cells) after induction of apoptosis with 5-fluoro uracil, where the same peak intensities $\left(782,1092,1320,1340,1578\right.$ and $1655 \mathrm{~cm}^{-1}$ ) decreased. These changes within spectra were used as a second parameter in defining apoptosis after it was confirmed in the first instance with confocal microscopy by staining the DNA of treated cells with Hoechst 33258 (DNA intercalator). It was concluded that a decrease in the intensity of peaks assigned to nucleic acids, proteins and lipids are associated with apoptosis [10].

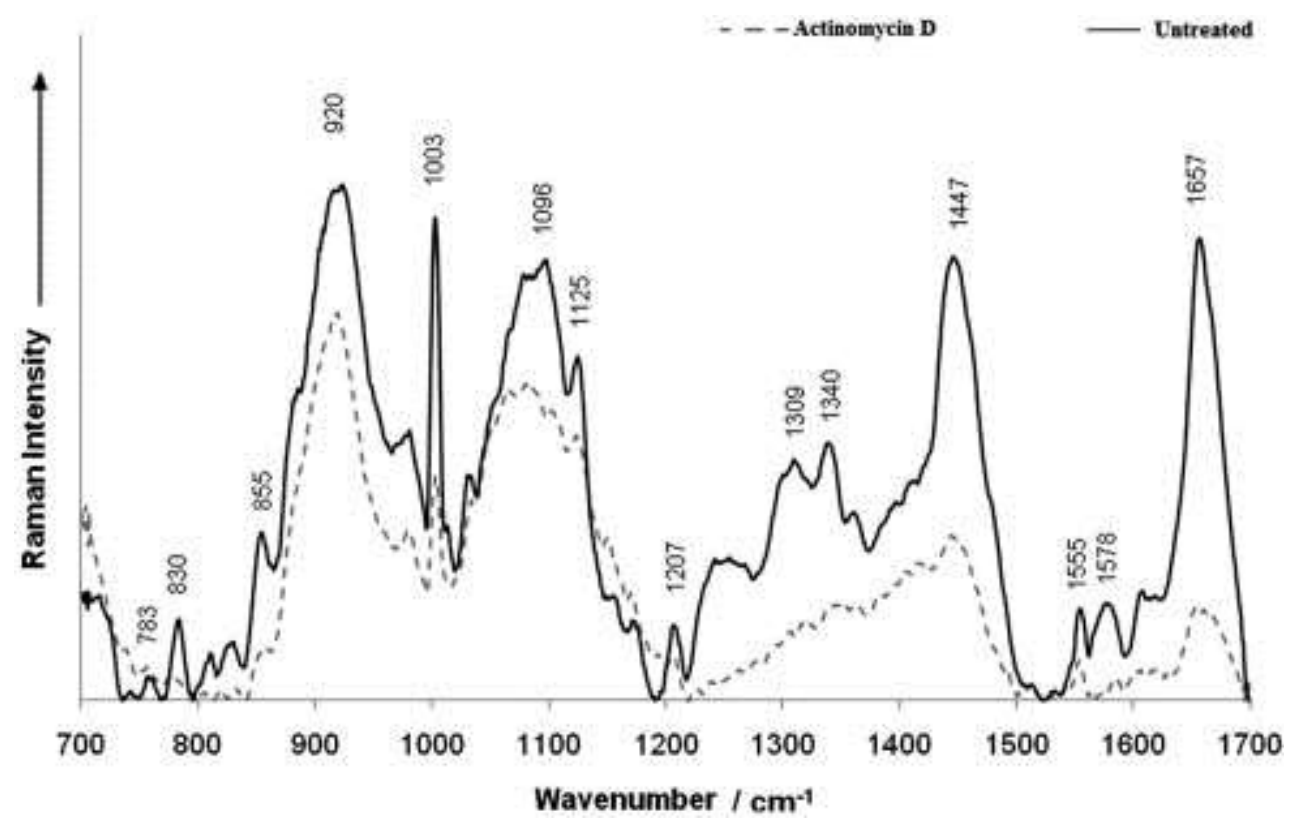

Fig. 5. Representative spectra of untreated dried U-937 cells and actinomycin D treated dried U-937 cells.

\section{Impact of increasing concentrations of ethanolic extract of the leaves}

Dose-dependent differences were observed between the morphology of the cells for the respective 
treatments and in comparison to the vehicle treated cells the changes were extreme (Fig. 2d). Cells treated with the extract had shrunken quite significantly, definite signs of cell death are observed and apoptotic bodies and membrane blebbing are clearly visible (Fig. 2c) [19]. Although the morphological signs, as observed with light microscopy, corresponded to apoptosis, flow cytometry measurements established that apoptosis only took place in $10-20 \%$ of the cells analysed [1]. The only other possible alternative mechanism of action of the treatment is autophagy, which displays similar morphological changes such as partial chromatin condensation and plasma membrane blebbing [20]. No publications could be found describing induced autophagic cells investigated with micro-Raman spectroscopy.

The cells were very sensitive to the laser and the laser power was decreased to $2 \mathrm{~mW}$ to prevent the cells from photo degradation during measurements. Treatments with the lower concentration $\left(\mathrm{IC}_{50}\right)$ affected the Raman spectra (Fig. 6) differently in comparison to DMSO or actinomycin D treated cells (Fig. 4 and Fig. 5). The amide I peak at $1657 \mathrm{~cm}^{-1}$ has disappeared and the peak at $1003 \mathrm{~cm}^{-1}$ of phenylalanine has drastically decreased in intensity, which indicate that proteins were exocytosed/extracted from the cells. New Raman bands appeared in the region between 1150 and $1700 \mathrm{~cm}^{-1}$, related to base structures and base-pairing, with higher intensities than the peaks in the spectra of the untreated cells. It has been shown that bands assigned to localised vibrations of these bases exhibit pronounced intensity increases during DNA melting [21]. The peaks in this region which showed hyperchromic behaviour are 1340,1487 and $1578 \mathrm{~cm}^{-1}$ representing purine bases and $1378 \mathrm{~cm}^{-1}$ representative of pyrimidine bases [8], [21] and [22]. A peak appeared at $1262 \mathrm{~cm}^{-1}$, which is usually attributed to protonated cytosine, but the amount of plant extract used could not have lowered the $\mathrm{pH}$ to such an extent as to protonate cytosine [14]. The addition of the complete 
medium containing phenol red, which becomes yellow at acidic conditions, confirmed this. It is speculated that another entity bound to cytosine resulting in a similar shift of the peak position. A peak appeared at $1692 \mathrm{~cm}^{-1}$ which is an indication of $\mathrm{C}=\mathrm{O}$ bonds, which are not hydrogen bonded. The peak at $1126 \mathrm{~cm}^{-1}$ representing $\mathrm{C}-\mathrm{C}$ lipid vibrations also increased in intensity and at $1193 \mathrm{~cm}^{-1}$ a new peak appeared usually associated with the amino group of cytosine [22]. Taking all of this into consideration it is highly probable that DNA melting occurred during the treatment and a complete re-arrangement of the molecular content of the cells took place. The changes in the Raman spectra are on a much larger scale that those reported in the literature for cell death and apoptosis from experiments where usually one parameter at a time is varied and changes in the Raman spectra monitored. In many instances extensive statistical analyses of the data is necessary to observe any significant change. A lack of published research in the area of phytomedicine using Raman spectroscopy and the fact that crude plant extracts contain a variety of unknown compounds make it difficult to analyse the data in more detail.

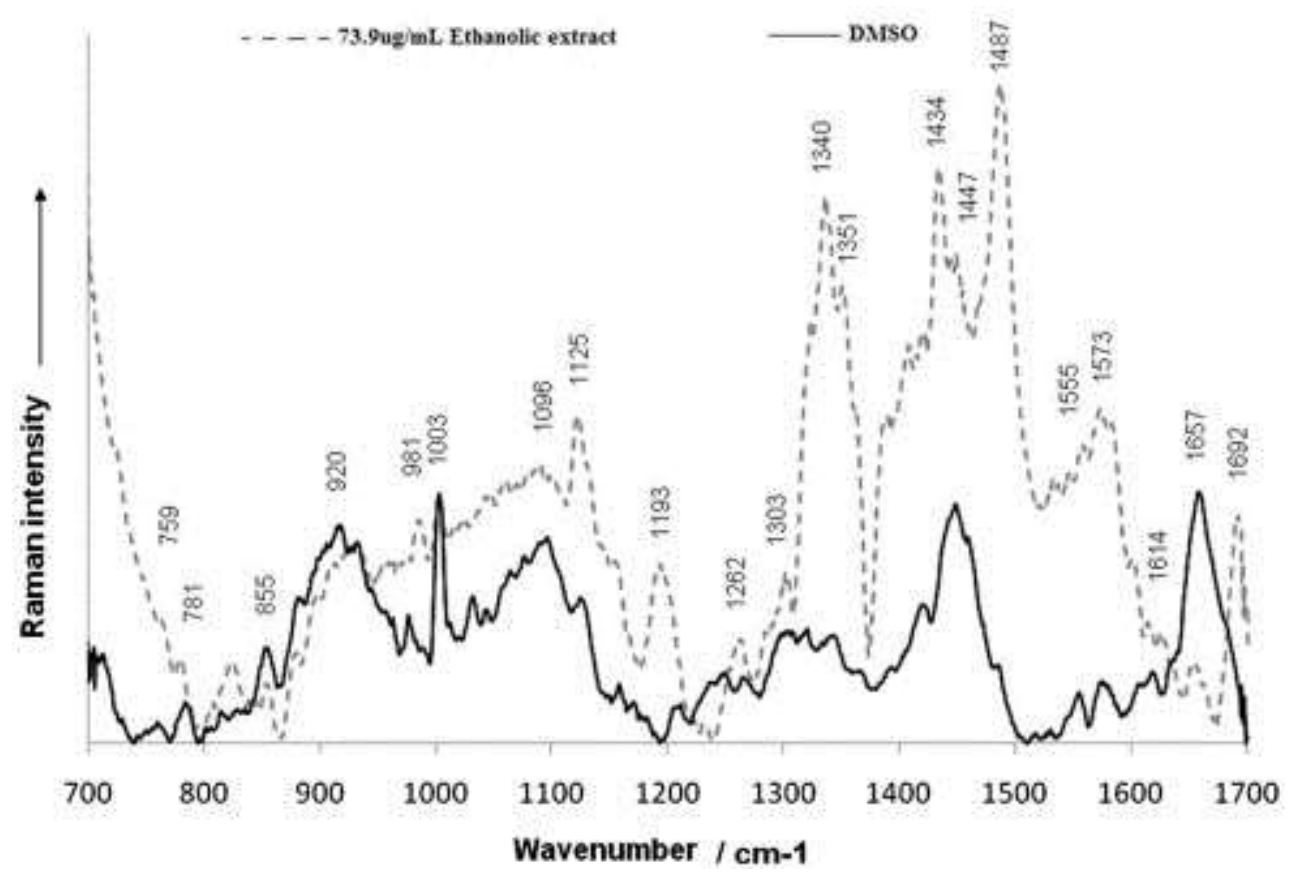

Fig. 6. Representative Raman spectra of DMSO and extract $\mathrm{IC}_{50}$ treated U-937 cells. 
Upon treatment with twice the $\mathrm{IC}_{50}$ concentration $\left(2 \mathrm{IC}_{50}\right)$ the spectra of the cells did not resemble the original spectrum of U-937 cells at all (Fig. 7). The most prominent peak in the spectrum is located at $1487 \mathrm{~cm}^{-1}$, usually assigned to guanine and adenine. Other peaks occur at $1573(\mathrm{dG}, \mathrm{dA})$, $1434\left(\mathrm{CH}_{2}\right.$ stretching), 1303 (adenine), 1262 (protonated cytosine), 1193 (tyrosine, phenylalanine) and $1125(\mathrm{C}-\mathrm{C}$ stretch $) \mathrm{cm}^{-1}$. In comparison to cells treated with actinomycin D it is clear that the cell response was completely different.

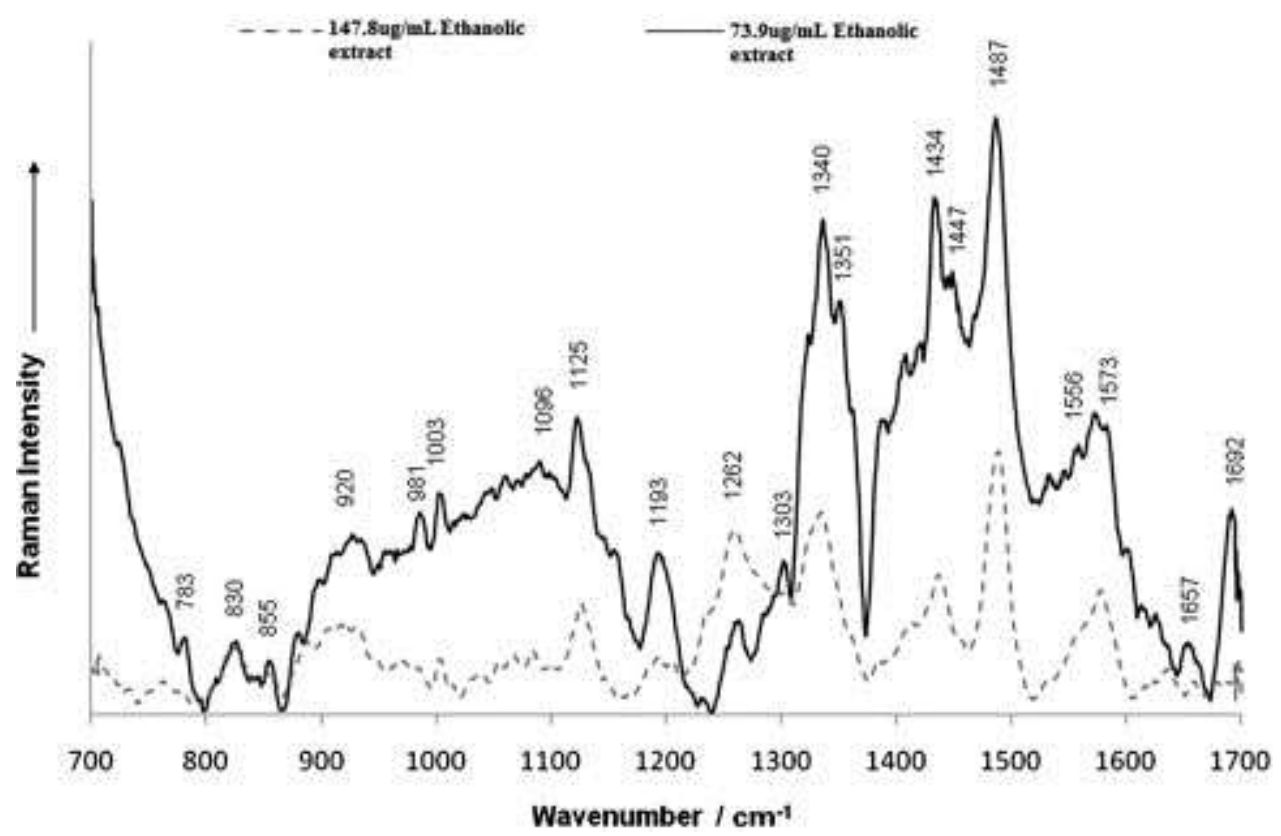

Fig. 7. Representative Raman spectra of $C$. agatiflora $\mathrm{IC}_{50}$ and $2 \mathrm{IC}_{50}$ treated U-937 cells.

In both cases it is obvious that the cells are not viable after treatments. This is in agreement with the results obtained from cytotoxicity tests, using a colorimetric assay using "sodium 3'[1(phenylamino-carbonyl)-3,4-tetrazolium]-bis-[4-methoyx-6-nitro) benzene sulphonic acid hydrate" (XTT) [1] and [2]. However, flow cytometry measurements indicated that only $10-20 \%$ of the cells showed signs of apoptosis after treatment with both concentrations of extract [1] and [2]. Further work is necessary where other types of cell death or disruptions of cell metabolism should also be investigated.

\section{Impact of the isolated compound, madurensine on U-937 cells}

It was not possible to take light microscopy photographs of madurensine treated cells due to the small quantity of compound isolated, but flow cytometry showed that the cells were still viable and 
therefore considered to be autophagic. All the Raman peaks decreased significantly in comparison to the Raman spectrum of DMSO treated cells, which is indicative of lower concentrations of proteins and lipids (Fig. 8). However, the basic profile of the spectrum is still the same as for the untreated cells and although decreased in intensity most peaks can still be recognised and also have similar relative intensities.

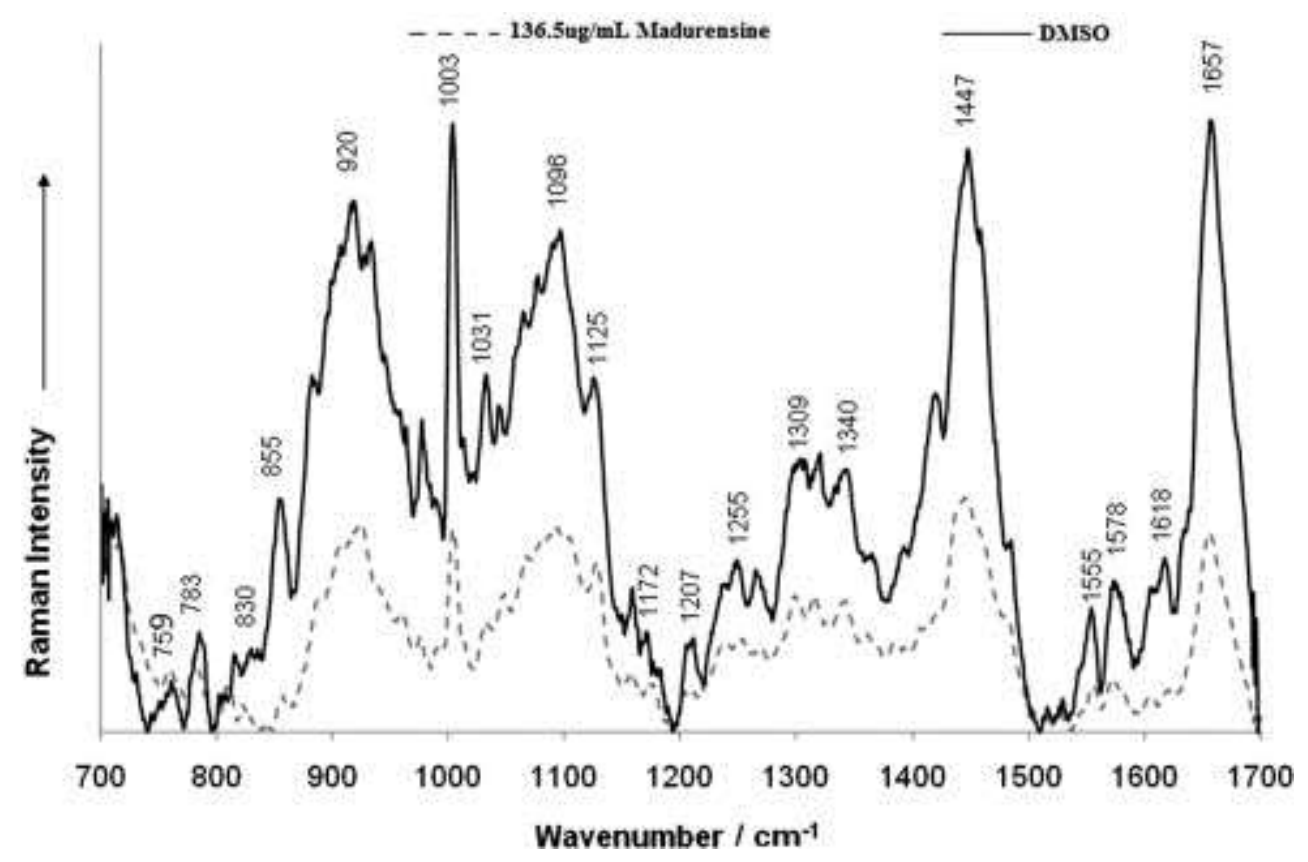

Fig. 8. Representative Raman spectra of DMSO and madurensine treated cells.

In Fig. 9 this spectrum is compared to that of the cells treated with the positive control actinomycin $\mathrm{D}$ in order to compare the Raman spectra of apoptotic and predicted autophagic cells. In both spectra the concentrations of proteins and lipids have decreased significantly, but in contrast to the madurensine treated cells but there are slight differences in comparison to the spectrum of the untreated cells. In the region $1200-1400 \mathrm{~cm}^{-1}$ the peaks are much better defined in the madurensine treated cells than in the spectrum for the actinomycin D treated cells and might be an indication of actinomycin D binding to DNA. The Raman spectra of madurensine treated cells were completely different to both spectra of the extract treated cells. 


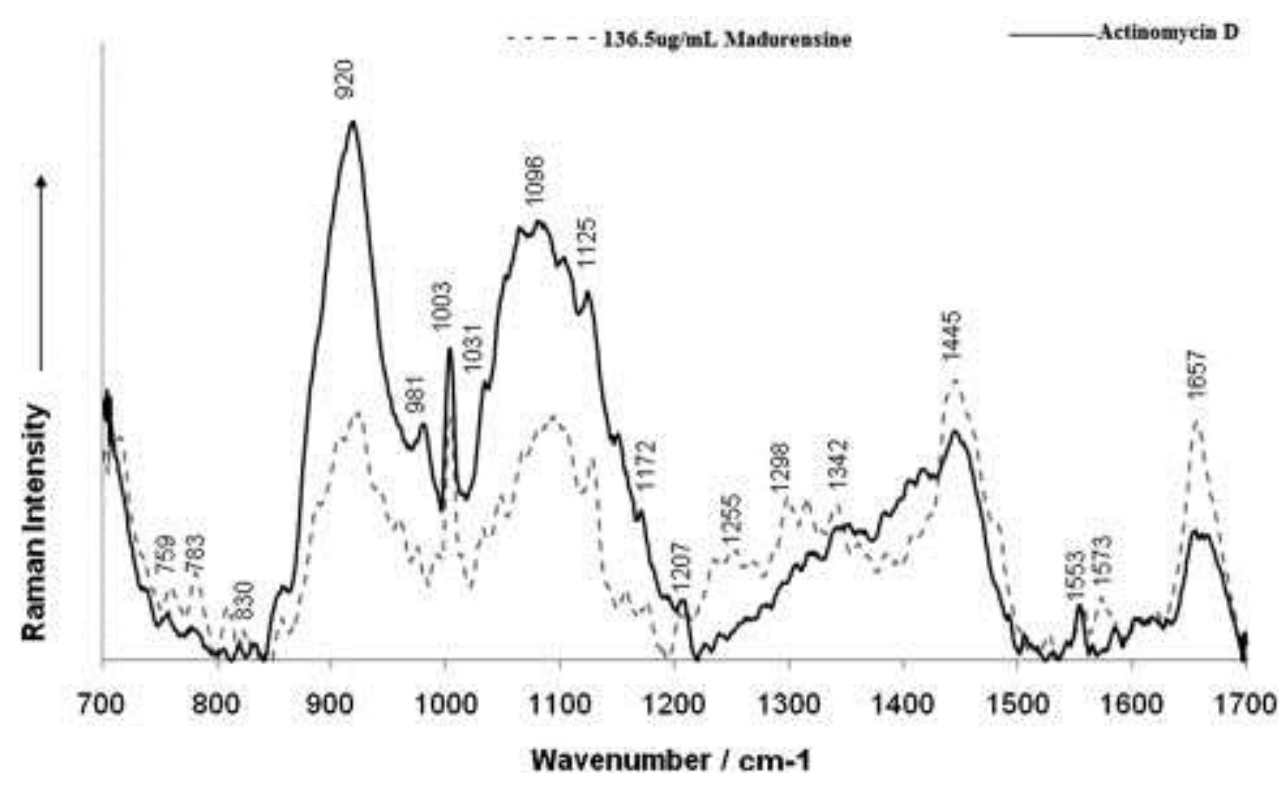

Fig. 9. Representative Raman spectra of actinomycin D and madurensine treated cells.

Only two similar investigations could be found, one of which was a short communication [22] and the other a Brazilian thesis [23]. The affects of Nerium oleander on prostate cancer cells (PANC1) were investigated and it was found that treatment with high concentrations affected protein and lipid composition dramatically. It was also found that Raman spectroscopy is a powerful tool to determine the variation of chemical composition within cells [24]. Both findings were confirmed in the present study. Autophagy and apoptosis had very similar spectra and thus could not be distinguished by micro-Raman spectroscopic analysis alone.

\section{Conclusions}

Increasing concentrations of the ethanolic crude extract of the leaves of C. agatiflora altered the composition of the biochemical material of the treated cells significantly according to changes observed in the Raman spectra of the cells. The drastic changes in cell structure are possibly due to the extraction of proteins and accompanying DNA melting. The same effect was not observed in the Raman spectra of the madurensine and actinomycin D treated cells, where the main changes in the spectra were due to a decrease in intensity of all the bands, which can be related to a decrease in the concentration of proteins and lipids in the cells. This is a interesting result, as the results obtained 
using more conventional methods such as flow cytometry and light microscopy did not distinguish between the three treatments.

The investigation showed that micro-Raman spectroscopy could be used for initial screening of samples to determine the effects of different treatments on cancerous cell lines, which will save time and be less expensive than trying to find leads on the mechanism of action using conventional methods. Furthermore, in combination with conventional methods Raman spectroscopy can be a powerful tool in distinguishing between different kinds of cell death. The results also highlights the fact that for many natural products used for medicinal purposes the therapeutic effect of the crude plant extract tends to be significantly more effective than the particular action of some of its constituents.

\section{References}

[1] K. Le Roux, A.A. Hussein, N. Lall. Phytomedicine. 2011, Submitted. (MSc. Thesis)

[2] V. Tene, O. Malagon, P.V. Finzi, G. Vidari, C Armijos, T. Zaragoza. J. Ethnopharmacol. 2007, 111, 63 .

[3] J.G. Graham, M.L. Quinn, D.S. Fabricant, N.R. Farnsworth. J. Ethnopharmacol. 2000, 73, 347.

[4] J. Guo, W. Cai, B. Du, M. Qjan, Z. Sun, Biophys. Chem. 2009, 140, 57.

[5] P.V. Zinin, A. Misra, L. Kamemoto, Q. Yu, N. Hu, S.K. Sharma, J. Raman Spectrosc. 2010, 41, 268.

[6] C.M. Shachaf, S.V. Elchuri, A.L. Koh, J. Zhu, L.N. Nguyen, D.J. Mitchell, J. Zhang, K.B. Swartz, L. Sun, S. Chan, R. Sinclair, G.P. Nolan, PLoS ONE. 2009, 4, 1.

[7] N.R. Petersen, C.H. Nielsen, Spectroscopy Online. 2009 Available: http://spectroscopyonline.findanalytichem.com/spectroscopy/article/articleDetail.jsp?id=637198 [Cited 19 January 2011].

[8] C. Krafft, T. Knetschke, A. Siegner, R.H.W. Funk, R. Salzer, Vib. Spectrosc. 2003, 32, 75.

[9] H. Yao, Z. Tao, M. Ai, L. Peng, G. Wang, B. He, Y. Li, Vib. Spectrosc. 2009, 50, 193.

[10] G.J. Thomas, Annu. Rev. Bioph. Biom. Struct. 1999, $28,1$.

[11] J.M. Benevides, S.A. Overman, G.J. Thomas, J. Raman Spectrosc. 2005, 36, 279.

[12] G.J. Pupples, H.S.P. Garritsen, J.A. Kummer, J. Greve, Cytometry 1993, 14, 251. 
[13] C. Matthaus, B. Bird, M. Miljkovic, T. Chernenko, M. Romeo, M. Diem, Method Cell Biol. 2008, 89, 275.

[14] A. Bankapur, E. Zachariah, S. Chidangil, M. Valiathan, D. Mathur, Plos One. 2010, 5, 10427.

[15] A. Stander, S. Marais, V. Stivaktas, C. Voster, C. Albrecht, M-L. Lottering, A.M. Joubert, J. Ethnopharmacol. 2009, 124, 45.

[16] S. Neidle, Nucleic structure and recognition, Oxford University Press, Oxford, 2002.

[17] N. Uzunbajakava, A. Lenferink, Y. Kraan, E. Volokhina, G. Vrensen, J. Greve, C. Otto, Biophys. J. 2003, 84, 3968.

[18] E.C. De Bruin, J.P. Medema, Cancer Treat. Rev. 2008, 34, 737.

[19] H. Lodish, A. Berk, P. Matsudaira, C.A. Kaiser, M. Krieger, M.P. Scott, L. Zipursky, J. Darnell, Molecular Cell Biology, $5^{\text {th }}$ ed., Freeman and Co., New York, 2005.

[20] R.B. Swain, S.J. Kemp, P. Goldstraw, T.D. Tetley, M.M. Stevens, Biophys. J. 2010, 98, 1703.

[21] A. Taleb, J. Diamond, J.J. McGarvey, J.R. Beattie, C. Toland, P.W. Hamilton, J. Phys. Chem. B. 2006, 110, 19625.

[22] M. Wink, Phytochemistry 2003, 64, 3.

[24] A. Saha, V.V. Yakovlev, J. Raman Spectrosc. 2009, 40, 1459. 